\title{
Poór József
}

\section{A HR-funkció átalakulása a Magyarországon müködő nemzetközi vállalatoknál egy empirikus felmérés tapasztalatainak tükrében}

\begin{abstract}
Magyarországon az első külföldi tulajdonú leányvállalatot 1973-ban a Siemens cég jegyeztette be. 1988tól kezdve tömegesen jelentek meg a nagy nemzetközi cégek leányvállalatai hazánkban. A közvetlen tőkeberuházások (Foreign Direct Investment) kiemelkedő motorjaiezek a vállalatok, melyek helye és szerepe az eltelt 19 év alatt nagyon sokat módosult. A jelzett cégek helyi menedzsmentje szempontjából kitüntetett szerepe van az emberi erőforrások menedzselésének. (A tanulmányban a hagyományos, nemzetközileg használt HRM rövidítés helyett az újabban terjedő HR változatot használjuk.) Az emberierőforrásmenedzsment irodalmában még nem található meg az átmeneti országok leányvállalatainál kialakult új HR-minták pontos leírása. Ez az új helyzet új tudást kíván, és annak megértését, hogy az embereket hogyan irányítják, fejlesztik, koordinálják a nemzetközi vállalatoknál hazánkban. Jelen tanulmány bemutatja a HR változását a nemzetközi vállalatok hazai leányvállalatainál elvégzett felmérésünk tükrében, a szervezeti életciklus változásának függvényében.
\end{abstract}

Journal of Economic Literature (JEL) kód: M16, M51, M52 és M54

Kulcsszavak: nemzetközi vállalatok, emberierőforrás-menedzsment, helyi leányvállalatok, életciklus- modell

Kutatási projektünk keretében a Magyarországon megtelepülő nemzetközi vállalatok leányvállalatainak HR-funkcióit és gyakorlati alkalmazásait, valamint mindezek történeti fejlődését vizsgáltuk. A hazai HR leggyakrabban idézett megfogalmazása szerint „Az emberierőforrás-menedzsment azon funkciók (pl. HR stratégiai, munkavégzési, erőforrás-biztosítási, teljesítményértékelési, fejlesztési-képzési, javadalmazási és dolgozói kommunikációs stb.) kölcsönösen egymásra épülő együttese, amelyek az emberi erőforrások hatékony felhasználását segítik elő az egyéni és szervezeti célok egyidejű figyelembevételével" (Poór et al. 1999 és Karoliny et al. 2003). A nemzetközi vállalatok esetében az előzőekben leírtak megvalósulását vizsgáljuk az adott országban foglalkoztatott munkavállalók esetében, az arra jellemző sajátos intézményi környezet keretei között (Dowling et al. 2008).

Poór József egyetemi tanár a Pécsi Tudományegyetemen.E-mail: poor@ktk.pte.hu

A tanulmányban támaszkodtunk Poór József - Engle, Allen - Gross, Andrew: Organization theory and the post-socialist transformation. Human Resource Management Practices of Large Multinational Firms in Hungary, 1988-2005 c. munkájára. Az életciklusmodellek hazai HR-ben való alkalmazását 2007-ben vizsgáltuk egy OTKA és OFA kutatás keretében Dr. Farkas Ferenc és Karoliny Mártonné Dr. kollégáim közremüködésével. 
Vizsgálatunkban arra kerestük a választ, hogy ezek a jelzett HR-funkciók és a gyakorlati alkalmazások hogyan alkalmazkodtak az elmúlt évek rohanó gazdasági változásai közepette. Alapvetö hipotézisünk az volt, hogy a vizsgált fejlödési szakaszokon átment leányvállalatok esetében tapasztalhatjuk azokat a jelenségeket, amelyeket hasonló érettségü leányvállalatok kapcsán a szakirodalomban más szerzők is publikáltak.

A HR-funkciót a nemzetközi cégek különbözö tevékenységeit felölelö, befolyásoló tényezők komplex rendszerében vizsgálják. A szakirodalomból jól ismert, hogy melyek azok a tényezők, amelyek befolyásolják a HR stratégiai kérdéseit. Ezzel összefüggésben Fisher et al. (1993) és Francesco és Gold (1997) úgy vélik, hogy ide sorolhatók a külső és belső tényezők, a vállalat fejlettsége az adott régióban, az alkalmazott technológia és nem utolsósorban a leányvállalat életciklusa. Az 1.ábra a nemzetközi menedzsment hatótényezőit és megvalósítási eszközeit foglalja rendszerbe. Így többek között javasolt modellünk a következőket tartalmazza:

1. ábra

\section{A kutatás modellje}

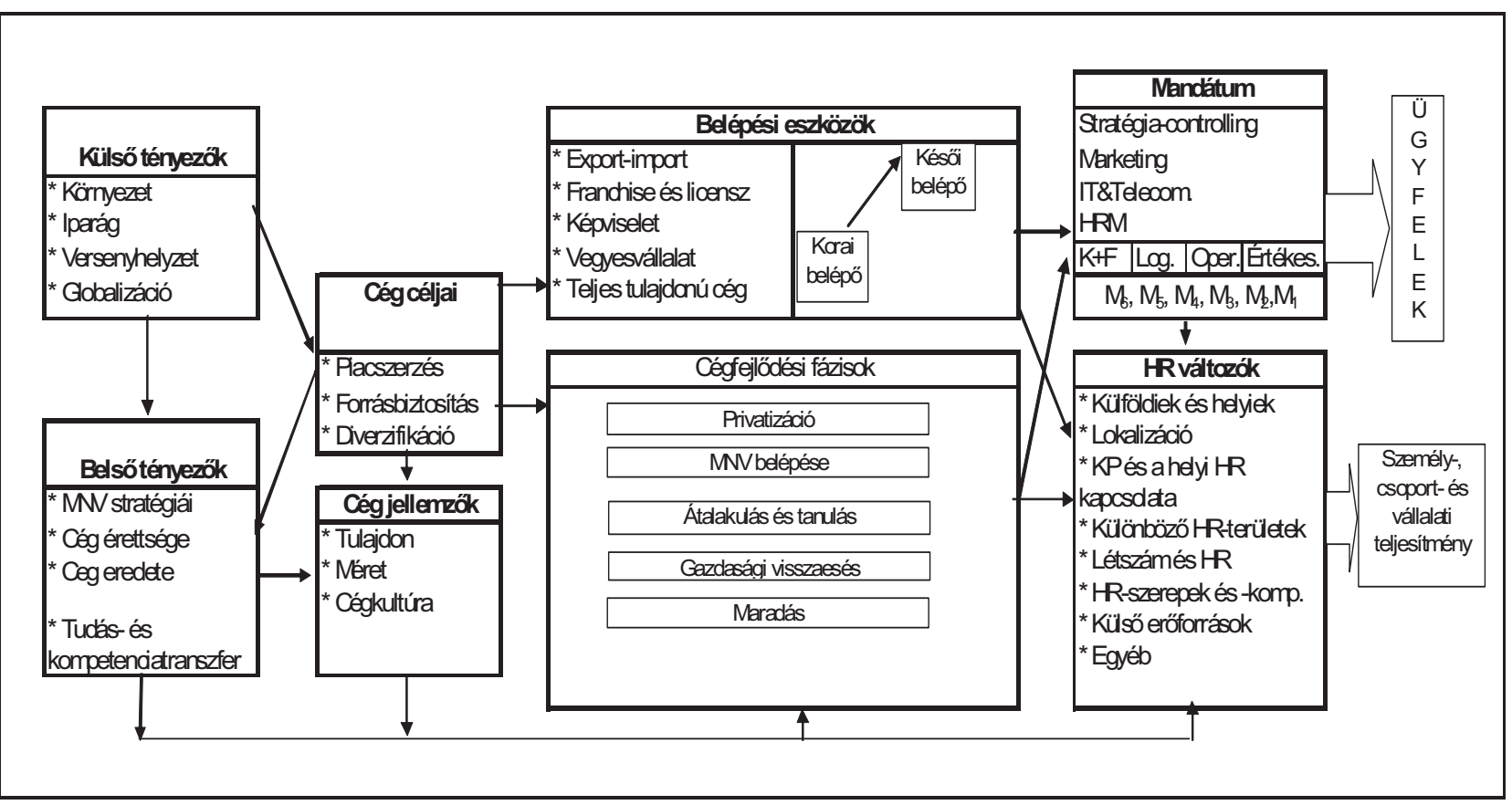

- Külső tényezők: A legfontosabb külső befolyásoló tényezők közé sorolhatók a gazdaságijogi, iparági, verseny- és intézményi környezet, a külföldi tőke szerepe és erőssége, valamint a globális tényezők.

- Belső tényezők: A leglényegesebb belső tényezők közül modellünk többek között a következőket hangsúlyozza: a stratégiai orientáció, a cég fejlettsége a térségben, a vállalat menedzsmentjének eredete és orientációja és nem utolsó sorban a tudástranszfer mechanizmusa.

- A cég céljai: a szakirodalomból jól ismert tény, hogy a multinacionális cégek más ország piacára történő belépésének nyilvánvalóan hagyományos okai és ezekből következő céljai vannak (piacszerzés, nyersanyagellátás biztosítása és diverzifikáció), de létezik számos új indok is (K+F-költségek emelkedésének az ellensúlyozása, méretgazdaságosság stb.).

- Belépési módok: Egy cég nem egy csapásra válik hatalmas globális vállalattá (Galbraith 
2000). Általában a vállalatok hosszabb evolúciós fejlődési mintákat követnek. Azonban „egyes vállalatok alkalmazhatják a licenceladási, alvállalkozási vagy egyéb müködési módokat is” (Dowling és Welch 2004:31). Azok a vállalatok, amelyek hajlandók „mindent kockára tenni, és fejest ugrani az ismeretlenbe", a revolúciós fejlődési mintát követik. $\mathrm{Az}$ új technológiák és a nem termékjellegű szolgáltatások rendkívül gyors fejlődése (pl. tanácsadás, média, bank- és pénzügyek) kínálta lehetőségek tartozhatnak ide. Ez utóbbi cégeknek létezik egy különleges csoportja is, amelyet „globálisnak született” cégnek hívunk. Ezek úgy is kiléphetnek a külföldi piacokra, hogy korábban nem volt hazai értékesítésük, és nem mentek végig az elöbb említett folyamaton (Oviatt - McDougall 1994).

- Mandátum: A helyi leányvállalatok lehetséges szerepeit ${ }^{1}$ az egyes tanulmányok nagyon különböző módon osztályozzák. A fontosságra alapozva Bartlett - Ghoshal (1998) az alábbi típusú leányvállalatokat különbözteti meg: jelentéktelenek, helyi jelentőséggel bírók, ígéretesek és stratégiailag fontosak. Az innovációban és a vállalati tudástranszferben betöltött szerepük alapján Black és szerzötársai (1999) a következö típusokat sorolják fel: sziget, alkalmazó innovátor, integrátor leányvállalat. Az említett szerzők nyomán a leányvállalatoknak az információáramlásban és a tudástranszferben betöltött szerepük szerint a következő szerepeket határozhatjuk meg: passzív-elfogadó, átalakító, tudástermelö és -átadó. A nemzetköziesedés és globalizáció szempontjából Adler (1997) úgy gondolja, hogy léteznek exportáló-importáló, átruházó, regionális és globális stratégiai központként funkcionáló leányvállalatok. Delany (1998), valamint White és Poynter (1984) aszerint, hogy a helyi leányvállalat milyen szintü ellenőrzést gyakorol az értékláncban, tevékenységi körük szélessége (pl. csak termelő, értékesítő vagy kutató-fejlesztő, termelő és értékesítő) alapján kategorizálják. Közbevetőleg jegyezzük meg, hogy jelen tanulmányban ez utóbbi modellt követjük

- Cégfejlődési fázisok: A 70-es évek óta sok szerző (Greiner 1972; Kazanjian 1988; Kazanjian - Drazin 1989; Hanks et al. 1994) foglalkozott az életciklus-elmélet vállalati kérdéseivel. Az életciklus-modelleket (angolul life cycle vagy stage model) a szervezeti növekedés vizsgálatára dolgozták ki. Az ilyen modellek alkalmazásának alapvető célja, hogy „segítségükkel a szervezeti növekedés különböző fázisaira, a befolyásoló tényezők függvényében meghatározzák a lényeges következményeket" (Rutherford et al. 2003:321). Nincs egyértelmü bizonyíték arra, hogy hány fázissal lehet leírni egy-egy szervezet életciklusát, ezek az értékek 3 és 10 között mozognak. Hosszú ideig a cégek különböző fejlődési fázisainak tükrében, inkább az általános menedzsment, a pénzügyi és az értékesítési-marketing kérdések álltak a kutatók vizsgálatainak középpontjában. Lavoie és Guilbert (1978), valamint Adizes (1992) úgy érvelnek, hogy a humán tényező, továbbá a dolgozói magatartásformák a szervezeti életciklus változááával együtt módosulnak. Hess (1987) úgy vélte, hogy az általános menedzsmentproblémák mellett a HR-kérdések a legfontosabbak a szervezeti növekedés egyes fázisaiban.

- HR-változók: A modellben a következő tipikus HR-változók alakulását (Dowling et al. 2008) vizsgáljuk: külföldiek és helyiek, lokalizáció, központ (KP) és a helyi HR kapcsolata, különböző HR-területek, vállalati létszám és HR, kompetenciák és HR-szerepek, külső erőforrások (szolgáltatók) stb.

\footnotetext{
A tanulmányunkban használt mandátum kifejezés sok hasonlóságot mutat a szakirodalomban széles körben elterjedt értéklánc (value chain) fogalommal. A mandátum fogalmat azért preferáljuk a cikkünkben, mivel az anyavállalat által az értékláncban betöltendő leányvállalati szerepet kívánjuk még jobban kiemelni.
} 


\section{Életciklus modellek tipikus fázisai}

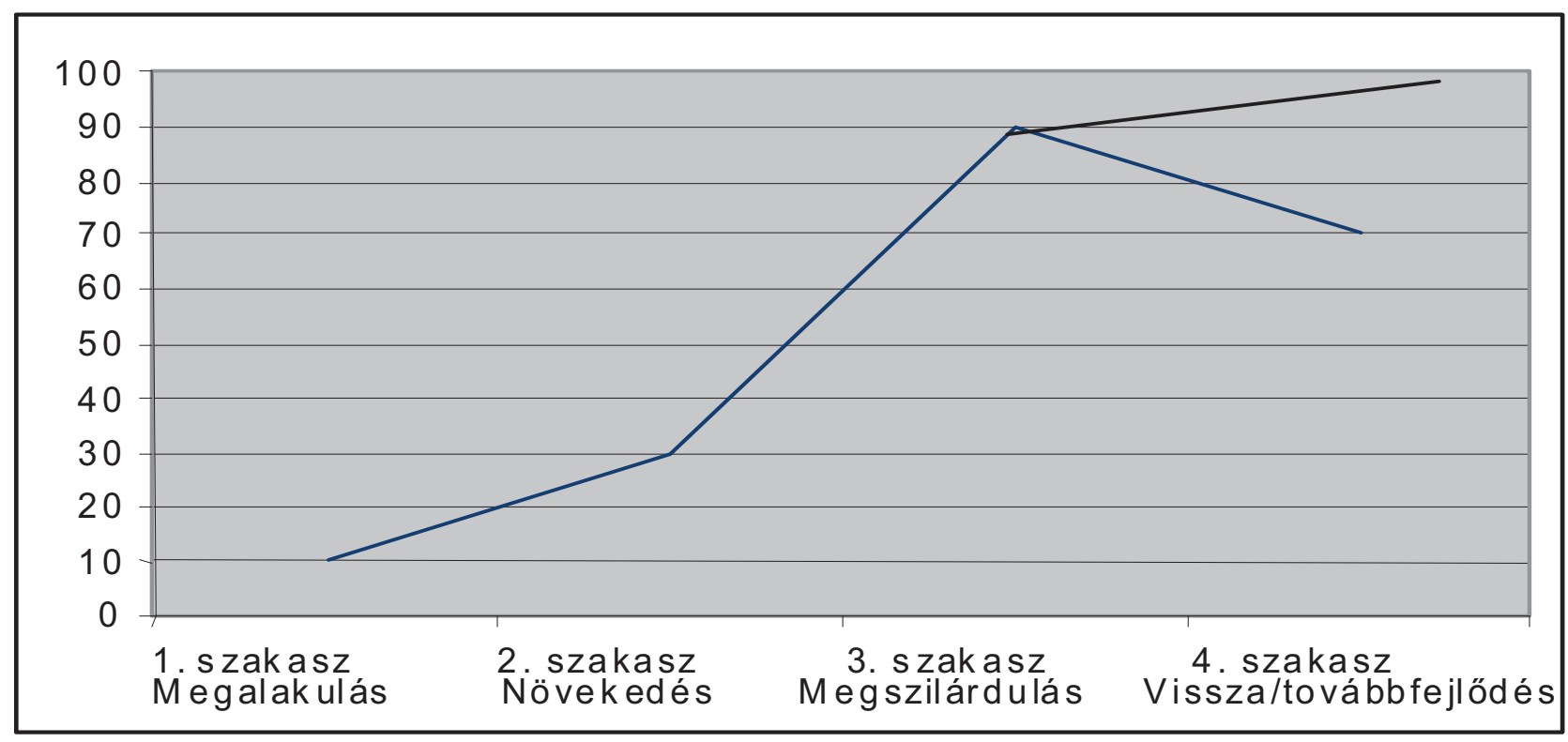

$\mathrm{Az}$ előzőekben leírt szakirodalmi megállapításokra támaszkodva úgy véltük, hogy a nemzetközi vállalatok helyi leányvállalatainak HR-gyakorlata változásának vizsgálatára - az elmúlt 19 évre vonatkozóan - alkalmazható az előzőekben bemutatott modell. $\mathrm{Az}$ alapvető kutatási szakaszokat alább ismertetjük, a kutatás modelljét pedig a 2. ábra mutatja be. (E lépések közül az első három szakasz átfedi egymást, ahogyan az egyes vállalatoknál tapasztalható is. Az időpontokat megközelítőleg tüntettük fel, alkalmazkodva a makrogazdasági viszonyokhoz, ahogyan azok Magyarországon változtak.)

- 1. szakasz. „Privatizáció”: Ez az átmeneti időszak - amely a minta szempontjából a 80-as évek végétől a 90-es évek második feléig tartott - a magyar gazdaságban a centralizált államiirányításból, a szocializmusból a termelésierőforrások magánkézbe valókerülésével jellemezhetö. Mind a jogi, mind pedig az intézményesített keretek (magántőke, piacok kialakulása stb.) megváltoztak, ezáltal lehetővé vált a magántulajdon és a tőkeallokáció számos formája. Hazánkban a spontán privatizáció 1988-ban kezdődött és a 90-es évek végére az OTP-részvények eladásával döntő mértékben be is fejeződött (Branyicki et al. 1992; Roóz 1996; Major 1999).

- 2. szakasz. „Az MNV-k megjelenése”: Ebben az időszakban - mely vizsgálatunk szempontjából átfogja a 80-as évek végétől a 90-es évek végéig terjedő időszakot jelentek meg a multinacionális vállalatok (MNV) a magyar gazdaságban az államilag támogatott, állami tulajdonú vagy már korábban privatizált vállalatokon keresztül, a helyi vagy regionális tulajdonú vállalati tranzakciók, a zöldmezős beruházások révén. Ezek az akvizíciók vagy zöldmezős invesztíciók az eladástól és értékesítéstől kezdve a teljes értéklánci folyamatot átfoghatták. A termelési kapacitások, az emberi erőforrások, a technológiák és folyamatok átvilágítása és elemzése jellemzi ezt az időszakot. Nem minden nemzetközi vállalat kezdte nulláról magyarországi befektetéseit. Például az IBM 1936 óta van jelen hazánkban, és három év (1969-1972) kivételével mind a mai napig folyamatosan müködik is. A volt szocialista országok közül hazánkban jöhettek létre 
legelöször (1972-ben) a vegyesvállalatok. Ahogy már jeleztük, ezzel a lehetőséggel nálunk legelöször a Simens AG élt, amely 1973-ban alapította meg első itteni vegyesvállalatát. A legtöbb külföldi cég azonban a rendszerváltás után hajtotta végre tőkebefektetéseit hazánkban.

- 3. szakasz. „Átmeneti időszak, tanulás-fejlődés” (1988-1999): A „mézeshetek” időszaka alatt - amely a 90-es éveket jelenti - a terjeszkedő nemzetközi cégek felmérték a helyi vállalati gyakorlatot és folyamatokat. Ezek a cégek ,jó állampolgárként” a hazai standardok szerint megkíséreltek megfelelő egyensúlyt találni a helyi termelés, a technológiák, az emberi képességek és folyamatok elfogadható formalizálása révén. A helyiek aggodalmát megértve, megpróbáltak alkalmazkodni a helyi érdekviszonyokhoz, kötődésekhez és szokásokhoz.

- 4. szakasz. „Gazdasági visszaesés” (2000-2003): A világgazdasági visszaesés egybeesett a „mézeshetek” vagy sikeres átalakítások lezárulásával. Megfigyelhető volt egy reálisabb elvárási rendszer kialakulása helyi és globális szinten, ami a gazdasági racionalitást és a veszteséges részlegektől való megválást vonta maga után. A tevékenységek mindinkább a regionális szemléletnek megfelelően folytak, és a fölösleges termelési folyamataikat és tevékenységeiket áthelyezték a régió vagy a világ más részeibe. A technológiai és személyügyi fejlesztésekre szánt befektetéseket vagy elhalasztották, vagy visszavonták.

- 5. szakasz. „Megszilárdult állapot” (2003-tól napjainkig): A relatíve globális gazdasági stabilitás és a további európai egyesítés együttes hatása lélegzetvételnyi szünetet eredményezett ahhoz, hogy a nemzetközi vállalatok újraértékeljék magyar leányvállalataik potenciális szerepét az elmúlt 19 évet jellemező állandó változások és bizonytalanságok után. (Ma már látszik, hogy a néhány éves prosperitás után újabb globális visszaesés jelei mutatkoznak, e krízis következményeinek vizsgálata azonban nem tárgya elemzésünknek.)

\section{Hipotézisek}

Vizsgálataink során a következő kutatási hipotéziseket alkalmaztuk:

- H1: A nemzetközi vállalatok HR-részlegeinek felelőssége jelentősen változott a vizsgált időszakban. A személyzeti kérdések fontosságának növekedésével a HR egyre inkább megosztja a felelősséget a vonalbeli menedzsmenttel.

- H2: A HR-vezetők elsődleges felelőssége csak a munkavállalói érdekegyeztetésre, valamint a fizetésekkel és juttatásokkal összefüggő döntésre terjed ki.

- H3: A leányvállalatok életciklusának különböző fázisaiban eltérő HR-kérdések válnak fontossá.

- H4: A struktúraváltást követő életciklus-időszakban csökken a külföldi kiküldöttek (expatriates) és nő a helyi, a központhoz kiküldött magyar szakemberek (impatriates) száma.

- H5: Mivel az átalakuló országokban a HR-munka színvonala alacsony szintü volt, a különböző nemzetközi vállalatok megpróbálják centralizálni a legtöbb HR-funkciót.

- H6: A nemzetközi vállalatok leginkább a tréning- és a vezetésfejlesztési funkciókat szervezték ki külső szolgáltatóknak.

- H7: Történelmi okok miatt mind a mai napig az ipari dolgozók szervezettségi szintje viszonylag magas. 


\section{Leányvállalati vizsgálat}

\section{A kutatás jellemzői}

A választott kutatási módszert meghatározta az a tény, hogy a vizsgált öt időszakra vonatkozó ismereteket személyes interjúval lehetett a leghatékonyabban összegyüjteni. A kutatástervezés „szekvenciális logikáját” alkalmazva (Hellriegel et al. 1998) a HR átalakulását a helyi vállalati szakemberek közremüködésével tanulmányoztuk, még az interjúkat megelőzően, a leányvállalati fejlődés szakaszainak tükrében. Ezekről esettanulmányok készültek. A partnerek felkészülésének és a szükséges mennyiségi adatok összegyüjtésének megkönnyítése céljából egy 19 oldalas szempontrendszert küldtünkkiinterjúpartnereinknek. A szempontrendszer azon kérdéseire adandó válaszokat, amelyekhez háttéradatokat találtunk a cégek kiadványaiban és honlapján, beírtuk a kiküldött szempontrendszer megfelelő helyére. Az interjúk időtartama 2,5-3 óra volt. A meg nem válaszolt kérdéseket vagy a hiányzó adatokat nyitva hagytuk, és arra kértük interjúpartnereinket, hogy írásban válaszolják meg. Az interjúkban nemcsak arra próbáltunk választ adni, miért következett be valami, hanem arra is kerestük a megfelelö választ, hogy miért nem (Kieser 1995). A szempontrendszerre adott válaszokat elektronikusan rögzítettük, és ellenőrzés, esetleges korrekció végett megküldtük partnereinknek.

A 42 vállalati interjú statisztikai elemzésének megkönnyítése érdekében az interjúk során összegyüjtött és ellenőrzött adatokat kódoltuk, majd ezeket a válaszokat elemeztük. Az interjúkat kettő kivételével a szerző készítette. A felmérésre 2004-2005-ben került sor. $\mathrm{Az}$ adatok ellenőrzését és visszacsatolását a résztvevő cégek bevonásával 2005-2006-ban végeztük. Az interjúk során az alábbi területeket tekintettük át:

- A válaszadók adatait: személyes adatok és az előbb bemutatott öt elemzési szakasz során betöltött beosztásaik

- A vizsgált leányvállalatok adatait: legfontosabb gazdasági jellemzők (árbevétel, össz- és HR-létszám, az öt szakaszban betöltött mandátum /értéklánc általuk lefedett szakaszai)

- Az öt szakasz általános és HR-jellemzőit: a leányvállalat stratégiai orientációja, a HRfunkció fontossága, külföldiek jelenléte, személyzeti lokalizáció foka, helyiek külföldi kiküldetése, központ és helyi HR közötti szerepmegosztás, a helyi HR szerepe a különbözö emberierőforrás-menedzsment alrendszerek kialakításában és működtetésében, a megkérdezett szakemberek sikerét jelentő legfontosabb HR-kulcskompetenciák és szakmai fejlődésük alapvető forrásai

- A HRjövőjét: az elkövetkező 12-24 hónapban a HR szempontjából várhatóan bekövetkező legfontosabb változások

Megállapításainkat az általános statisztikai módszerek (átlag, gyakoriság, eloszlás) felhasználásával alapoztuk meg. A számos kiemelt kérdésre adott válasz feldolgozásából nyert adatokat grafikusan is megjelenítettük. A legtöbb elemzés a válaszok fóátlagához viszonyított százalékpontos eltéréseket reprezentálja, de egy-két helyen megtalálható a válaszok normál eloszlásait megjelenítő ábra is. Ahol lehetséges volt, korrelációs és megbízhatósági vizsgálatokat is végeztünk. 


\section{Résztvevö cégek}

A résztvevő cégek a következőkkel jellemezhetők:

Olyan nagyvállalatokat válogattunk ki, amelyek hosszabb-rövidebb időszak alattátmentek a korábban leírt öt fejlődési szakaszon. Fontos kiválasztási szempont volt az is, hogy a résztvevők között megtalálhatók legyenek német, osztrák és angolszász eredetüek ${ }^{2}$ mellett más országok cégei is. Végül 50 leányvállalatot kerestünk meg, melyek közül a felmérésben 42 külföldi tulajdonú cég vett részt. A résztvevő leányvállalatok közül 40 jogilag önálló cég volt, további kettő pedig gyáregységi kategóriába tartozott.

A résztvevők túlnyomó többsége (90,5\%) 250 főnél több dolgozót foglalkoztató nagy cég volt ${ }^{3}$. A kiválasztott mintába bekerült cégeknél dolgozik a magyarországi nemzetközi vállalatoknál foglalkoztatott dolgozói létszám 18\%-a (100.000fö) ${ }^{4}$. A résztvevők 94,2\%-a 5 milliárd forint éves árbevételnél nagyobb cég volt. Lawler (2006) korábban már említett kutatásai szerint a számos fontosnak ítélhető független változó mint vállalati stratégia, szervezeti forma nem játszott döntő szerepet az anyavállalati HR-gyakorlat transzferálásában. $\mathrm{Az}$ említett szerző (Lawler 2006) egyetlen fontos tényezőt tartott érdemesnek kiemelni: a vállalati nagyságot (pl. létszámot), amely döntő szerepet játszott az anyavállalati HRgyakorlat leányvállalatokhoz történő átvitelében. A nagyvállalatok bürokratikusabbak, mint a kicsik, de ha menedzsmentjük fontosnak véli bizonyos HR-rendszer(ek) átvételét, azt hatékonyabban és eredményesebben tudják a jelzett cégek megvalósítani.

A résztvevő cégek 11 különböző országból érkeztek hazánkba. A legnagyobb arányt amerikai (33,3\%), német (19\%) és francia cégek képviselték a mintában.

A felmérésben résztvevő cégek 33\%-a zöldmezős módon, míg a fennmaradó 67\%-uk felvásárlással egybekötött privatizáció, vagy az azt követő akvizíció útján lépett a magyar piacra. A vizsgált cégek többsége, a távközlési ágazatbelieket leszámítva, korai piacra lépők (early comers) ${ }^{5}$ közé sorolható.

A vizsgált szervezetek kivétel nélkül átmentek a kutatási modellben leírt fejlődési szakaszokon. A zöldmezös (green-field) cégeknél a folyamat sajátossága miatt kimaradt a privatizációs szakasz. A megkérdezettek többségének külföldi tulajdonosai a többségi irányítást, a zöldmezős beruházásokat a 80-as évek vége és a 90-es évek közepe között szerezték meg vagy hajtották végre.

\footnotetext{
${ }^{2}$ Az interkulturális menedzsment kutatásában többféle módszer szerint próbálják a különféle szerzök a különböző országokat csoportosítani. Számos kultúramodell ismert a szakirodalomból. Egyik tipikusan alkalmazott módszer az ún. globális klasszterezés (cluster), ami nem jelent mást, mint meghatározó jellemzök mentén a különböző országokat csoportosítása (Peng 2009). Itt alapvetően arra ügyeltünk, hogy az ismertebb menedzsmentkultúrák képviselve legyenek a mintánkban.

${ }^{3}$ A KSH (2002) adatai szerint a nemzetközi cégek aránya alig éri el az összes vállalkozások számának a 3 százalékát, míg a nagyvállalatok között ez az arány jóval meghaladja a 80\%-ot.

${ }^{4}$ Az UNCTAD (2008) jelentése szerint a nemzetközi vállalatok a helyi leányvállalataiknál több mint 80 millió dolgozót foglalkoztatnak a világon. Országonként nagyon eltérő, hogy ez az érték hány százalékát jelenti az adott országban az üzleti életben foglalkoztatottaknak. A jelentés reprezentatív adatai szerint Irrországban a magánszférában dolgozók 50,6\%-a dolgozik a multiknak. Hazánkban ugyanez az érték szintén igen magas, 22,4\%-ot ért az említett jelentés szerint. A hazai magánszektorban foglalkoztatott 2,7 millió munkavállaló közül 606 ezer dolgozik a jelentés szerint a nemzetközi cégek helyi leányvállalatainál.

${ }^{5}$ Ezen elmélet szerint az elsőként új termékével vagy szolgáltatásával piacra lépő cég az, amelyik jelentös elönyre tehet szert más vállalatokkal szemben egy adott ország piacán. Ez a stratégia föleg olyan iparágakban lehet sikeres, ahol kevés cég található. Ha az adott iparágban nagyon sok cég müködik, akkor ez az elmélet nem igazán alkalmazható a különböző szervezetek közötti nemzetközi versenyképesség magyarázatára (Wild et al. 2003).
} 


\section{A vizsgált cégek eredete}

\begin{tabular}{|l|c|c|}
\hline Eredet & Gyakoriság & $\begin{array}{c}\text { Százalékos megoszlás } \\
(\%)\end{array}$ \\
\hline USA & 14 & 33,3 \\
\hline Német & 8 & 19,0 \\
\hline Francia & 4 & 9,5 \\
\hline Brit & 3 & 7,1 \\
\hline Holland & 3 & 7,1 \\
\hline Svéd & 3 & 7,1 \\
\hline Osztrák & 2 & 4,8 \\
\hline Dél-afrikai & 2 & 4,8 \\
\hline Finn & 1 & 2,4 \\
\hline Svájci & 1 & 2,4 \\
\hline Izraeli & 1 & 2,4 \\
\hline Összesen: & 42 & 100,0 \\
\hline
\end{tabular}

A szakirodalomból ismert, hogy a nemzetközi cégek hagyományos (piacszerzés, nyersanyagforrások biztosítása és diverzifikáció) és új okok (K+F-költségek és a gazdaságos üzemméret növekedése) miatt lépnek egy másik ország piacára (Hill 2002; Wild et al. 2003). A válaszadó cégek közel kétharmada (78,6\%) kizárólag új piacok megszerzéséhez kapcsolódó hagyományos motívum alapján érkezett hazánkba.

A klasszikus versenystratégiák (növekedés, szintentartás és visszafejlesztés) (Barakonyi 1999; Wild et al. 2003) elemzéséhez kapcsolódóan azt tapasztaltuk, hogy a cégek több mint háromnegyed része (76,2\%-a) jelenlegi stratégiaorientációjának a növekedést jelölte meg. A szintentartás a cégek közel egynegyedére volt jellemző. Egy a mintában szereplö, 1992-ben hazánkba érkezett vállalatnál a felmérés időpontjában folyt a gyárbezárás előkészítése.

A vizsgálat során Delany (1998) és White - Poynter (1984) szerzők nyomán hat (M1M6) kategóriába soroltuk a résztvevőket abból a szempontból, hogy az értéklánc (value chain) mekkora hányadára terjed ki a helyi leányvállalat tevékenységi köre. Valamennyi vizsgált szakaszban, jellemzően 24-33\% között, a negyedik kategóriájú mandátumban (M4) működő cégek találhatók. Ezek a szervezetek nem ellenőrzik a teljes értékláncot, de az értéklánc számos részében fejtik ki tevékenységüket. Ezen felül a visszaesés időszaka óta jelentőssé vált az értéklánc nagyobb részét lefedő M5 kategóriához tartozó cégek száma. Ez azzal magyarázható, hogy azok a cégek, amelyek kitartottak és nem mentek el, inkább megerősítették itteni leányvállalataikat, valamint érettségük miatt növekedettleányvállalatuk stratégiai és globális (global sourcing) ${ }^{6}$ szerepe.

\footnotetext{
${ }^{6}$ A global sourcing itt azt jelenti, hogy a helyi leányvállalat müködésének fö célja nem a helyi piac ellátása, hanem a világ bizonyos vagy összes piacának ellátása.
} 


\section{Interjúpartnerek}

A megkérdezett vállalati szakemberek személyes jellemzői közül a következők emelhetők ki: $\mathrm{Az}$ interjúkban résztvevő szakemberek $54,8 \%$-a nő volt. A magas női részarány a HR vezetői beosztásokban az emberierőforrás-ágazatban jellemző megoszlást ${ }^{7}$ követi (Karoliny et al. 2003).

A résztvevők közel kétharmada 40 év fölötti, 38,1\%-uk 40 év alatti volt. Kivétel nélkül egyetemi, föiskolai vagy azzal egyenértékủ végzettséggel rendelkeztek. A későbbiekben látható táblázatból kitünik, hogy az alacsony kontextusú menedzsment kultúrákból (angol, amerikai, holland, ír és dél-afrikai) érkező cégeknél a HR-vezetők életkora szignifikánsan alacsonyabb volt, mint a többi cég esetében. Az alacsonyabb kontextusú menedzsmentkultúrákban Hall - Hall (1989) szerint viszonylag könnyü a kapcsolatépítés, kevésbé jellemző a szigorú hierarchia és a paternalizmus, és gyorsabb az üzleti kommunikáció.

$\mathrm{Az}$ interjúpartnerek 61,9\%-a társadalomtudományi, 38,1\%-uk müszaki-természettudományos és 4,8\%-uk egyéb alapvégzettségü volt. A nemzetközi vállalatok élen jártak a 90-es évek elején abban, hogy előszeretettel vettek fel erre a területre nemcsak társadalomtudományi végzettségű szakembereket (Poór - Karoliny 2005).

A HR napjainkban stratégiai pozíciót tölt be ezeknél a cégeknél (Poór - Karoliny 2005). Interjúpartnereink kettő kivételével HR-vezetők voltak. A két kivételt képező elsőszámú vezető esetében pedig feladataik közé tartozott a HR közvetlen felügyelete és irányítása. Meg kell jegyeznünk, hogy a privatizáció időszakában a HR nem töltött be stratégiai pozíciót ${ }^{8}$ az ilyen és hasonló vállalatoknál (Kövári 1995).

A megkérdezettek többsége (64,3\%) három évnél hosszabb idöt töltött el jelenlegi pozíciójában. Napjainkhoz képest a nemzetközi cégek betelepülésekor a válaszadók közel 50\%-a nem HR-pozícióban dolgozott. A kutatás megbízhatósága szempontjából fontos megemlíteni, hogy a válaszadók közel 80\%-a 3-5 éves időszakot töltött el a vizsgált vállalatnál HR-es vagy más nem HR-pozíciókban.

\section{HR-változók}

\section{Külföldi kiküldöttek}

Különböző kutatásokból ismert, hogy a leányvállalatokérettségével összhangban csökken a külföldi kiküldöttek ${ }^{9}$ száma (Shenkar - Nyaw 1995; Simai - Gál 2000). Ez a tendencia a japán cégekre kevésbé jellemző (Dowling - Welch 2004). (Ezt a tényt egy 2005-ös kutatásunkban

7 Csak közbevetőleg jegyezzük meg, hogy más HR-munkakörökben ez az arány jóval nagyobb. A legutóbbi Cranetvizsgálataink (Poór 2007) szerint a női munkaerő aránya a különböző HR-munkakörökben a világon átlagosan közel 60\%-os, míg Kelet-Európában, beleértve hazánkat is, 70-80\% között mozog.

8 Ez a helyzet azzal magyarázható, hogy igen alacsony volt a privatizációt megelőző korszakban - ahogy korábban a HR-szakembereket nevezték - a személyzetisek és a munkaügyisek presztízse. A jelzett időszak vezetői föleg adminisztratív célra használták a HR-t.

9 Egy nagyon jelentős differenciáló tényező a hazai és nemzetközi emberierőforrás-menedzsment között az, hogy nem egy ország, hanem sok különféle ország munkavállalóit foglalkoztatják a nemzetközi cégek. Az ún. külföldi kiküldöttek (expatriate, expat), akik egyik országból (pl. anyaország vagy harmadik ország) a másikba költözve, ott hosszabbrövidebb ideig tarró alkalmazásban a fogadó ország állandó lakosává válnak. A hagyományos expatriate fogalom újabban több országban is bővült, számos cég egyre több ún. nemzetközi munkavállalót/menedzsert (international assigner) alkalmaz. Ez utóbbiak nem kötődnek szorosan egy bizonyos országhoz. 
ki is mutattuk, amikor 101 japán kiküldött szakembert vizsgáltunk /Matus - Poór 2006/). Lawler (2006) kutatásaiban arra is rámutatott, hogy az amerikai kiküldöttek számának növekedése elősegítheti a hazai HR-gyakorlat közelítését az anyavállalati elvárásokhoz, de ebben a tekintetben is döntő a helyi HR-menedzser elköteleződése és szakmai jártassága.

A mintában szereplö azon cégeknél, amelyek külföldi kiküldötteket foglalkoztatnak, e szakemberek száma közepes korrelációt mutat a vizsgált vállalatok létszámával. A gazdasági visszaesés idején nem volt kimutatható ilyen korreláció. Alacsonyabb korrelációt mutat a külföldi kiküldöttek száma a jelenlegi időszakban.

A felmérésből kitűnik, hogy csökken a külföldi kiküldöttek száma a vizsgált cégeknél, 9\%-kal nőtt a kiküldötteket nem foglalkoztató cégek aránya, és 13\%-kal nőtt a kevesebb külföldi kiküldöttet foglalkoztató szervezetek aránya. Csökkenő tendencia figyelhető meg a külföldi igazgatótanácsi tagok esetében is.

Fontos tény az is, hogyan változott a külföldi kiküldöttek szerepe és funkciója. Mindhárom időszakban magasabb százalékban töltöttek be menedzseri pozíciót. Jelenleg a vizsgált vállalatok $31 \%$-a legalább egy expat menedzsert ${ }^{10}$ foglalkoztat. Ezzel szemben az átalakulás időszaka óta 23,9\%-kal csökkent a szakértői szerepben külföldieket foglalkoztató cégek száma.

A válaszadó szervezetek 33\%-a jelezte, hogy az átalakulás idején a központból érkeztek a külföldi kiküldöttek. Ez az arány mára 23,8\%-ra csökkent. A fentiekben leírt hasonló tendenciák Evans et al. (2002) szerint a fejlett nyugati országokban is megmutatkoztak, ahonnan 10 évvel leányvállalataik megjelenése után az amerikai, angol és holland cégek jelentős számban hazaküldték az expatokat.

\section{Lokalizáció}

Nagyon sok tényező függvénye az, hogy mikor kerül sor a több százezer eurós költséget jelentő külföldi kiküldöttek helyiekkel való felváltására. Szakirodalmi tapasztalatokból tudjuk, hogy felvásárlási esetekben jóval rövidebb (0-3 év) ez az időtartam, mint a zöldmezős beruházások esetében, ahol ez legalább 3-5 év. A cégek nemzeti hovatartozása is nagyban befolyásolja a lokalizációt. A japán és az európai cégeknél jóval hosszabb a kiküldetés időszaka, mint az amerikaiaknál (Evans et al. 2002).

\section{Magyar kiküldöttek}

A továbbiakban azt elemezzük, hogy a vizsgált öt időszak alatt hogyan alakult a magyar kiküldöttek száma és kiküldetésük célországa.

Rövidebb külföldi kiküldetés tanulási és ismeretszerzési célból már a nemzetközi cégek megjelenésekor is előfordult, azonban hosszabb külföldi kiküldetésre először az ún. átalakulási időszakban mentek a magyarok.

${ }^{10}$ A külföldi kiküldötteket az általuk betölthető szerepek alapján számos módon osztályozhatják. Így többek között betölthetnek problémamegoldó, anyavállalati képviselö („figyelö szem"), tanuló (kompetenciafejlesztő vagy karrierfejlesztö) szerepeket is. 
Jelentősen nőtt (38,1\%-ról 75,6\%-ra) a korábbi időszakokhoz képest a magyar kiküldötteket foglalkoztató cégek aránya. A vizsgált vállalatok közel kétharmadánál (61,9\%-ánál) van ma magyar kiküldött.

A lokalizáció egyik újabb jele, hogy folyamatosan növekszik a helyi kiküldöttek száma (Dowling et al. 2008). Többségük a régióban vagy más harmadik országban dolgozik. Valamelyest növekedett az elmúlt időszakokhoz képest a központokhoz (HQ) kiküldött magyar impatriate-k száma is. Ez azért is örvendetes, mivel Evans és szerzőtársai (2002) szerint a helyiek vezető pozícióba helyezése még csak a transznacionalizáción ${ }^{11}$ kezdte. Az igazi áttörést az jelenti, ha ezek a helyiek expat státuszba is kerülhetnek.

A magyarok nemzetköziesedésének az egyik gátja inkább majd az lehet, hogy esetleg nem hajlandók belépni a nemzetközi körforgásba, vagy ha nem sikerül ún. transznacionális mentalitást kialakítaniuk magukban (Evans et al. 2002). Számos válaszadó jelezte, hogy a tapasztaltabb magyar szakemberek nem szívesen vállalják a kiküldetést a balkáni országokba vagy pl. a szomszédos Romániába. Ez nem kedvező, mivel sok esetben a nagyobb nemzetközi pozíció elérésének lehetőségei a régiós kiküldetésen keresztül vezetnek.

\section{A központ és a helyi HR viszonya}

A továbbiakban azt vizsgáljuk, hogy a különböző időszakokban hogyan alakult a központ és a helyi HR viszonya ${ }^{12}$. Valamelyest növekedett a központ (HQ) centralizációja a visszaesés idején megindult globális standardizálás és költségtakarékosság nyomán. Ebben az időszakban a cégeknek csak egynegyede érezte úgy, hogy valamelyest szabadsága van a helyi HR-döntésekben ${ }^{13}$. Napjainkban ez az érték 35,7\%-ra nőtt. Ez a szabadság viszont a HR szolgáltató központok kialakulása, valamint a nemzetközi cégek szervezetének hálózatos irányba történő fejlődése miatt csökkenhet, továbbá feltehetőleg amiatt is, hogy a magyarországi leányvállalatok nem képesek kihasználni az adódó lehetőségeket. A szakirodalomból Bartlett - Goshal (1998:65) nyomán jól ismert az utoljára említett probléma, hogy a sikeresnek indult decentralizációból az lett, hogy a „helyiek újra feltalálták

11 A multinacionális cégek helyi vállalataik személyzetbiztosítása területén többféle orientációt követhetnek (Harris Moran 2001; Dowling et al. 2008). Így többek között ide sorolhatók az etnocentrikus, policentrikus, régiócentrikus és nem utolsósorban a transznacionális személyzeti politikák. Globális vagy transznacionális orientáció keretében a vállalat mind helyi, mind világviszonylatban egyaránt a legjobb szeretne lenni. Ez a magatartásmód feltételezi, hogy nem a nemzetiségi hovatartozás dönt a kulcspozíciók elosztásánál. Az ilyen cégeknél a helyi menedzsereket is bekapcsolják a cég általános ösztönzési és teljesítményértékelési rendszerébe. Az említett magatartási mód követését számos tényező akadályozza napjainkban. Így többek között megemlíthetjük a nemzeti nacionalizmusok újraéledését, a globális struktúra müködtetésének növekvő költségét, a sajátos kommunikációs nehézségeket és nem utolsósorban a szükséges menedzser emberanyag biztosításának problémáit.

12 Számos szerző (Schuler - Dowling - De Cieri 1993; Taylor et al. 1996) kiemeli, hogy minél eltérőbb a helyi és az anyaországbeli nemzeti kultúra, annál nehezebb a HR-rendszerek külföldről történő átvétele és helyi bevezetése. Lawler (2006) Ázsiában és Európában működő amerikai leányvállalatok körében elvégzett vizsgálatából azt szürte le, hogy a helyi cégek mérete a legdöntőbb befolyásoló tényező a HR-rendszerek átvétele és adaptálása tekintetében. Jogos a kérdés: melyik megoldást kell egy-egy konkrét esetben alkalmazni? Az említett szerzők erre azt a választ adják, hogy a külső és belső szervezetalakító befolyásoló tényezők hatásmechanizmusának eredőjétől függ az alkalmazható rendszer. Bizonyos esetekben befolyásoló tényezőnek tekintik a fogadó ország nemzeti kultúráját és a jogi, valamint szabályozási környezetet.

${ }^{13}$ A jelzett vélemények értékelésekor fontos utalni arra, hogy a több időszakra vonatkozó értékelés ugyanattól a személytől származik. 
a kereket". Ezért is ajánlják Evans és szerzőtársai (2002), hogy a felelösséget fokozatosan és meggondoltan kell átruházni a helyiekre.

A központ befolyása a vezetői munkakörök esetében a legjelentősebb. Ennél jóval kisebb a beosztott dolgozókkal összefüggő HR-kérdésekben. (A külföldi kiküldöttek esetében a helyi HR szerepe még jóval kisebb az elöbb leírtaknál.) Taylor és szerzötársai (1996) alátámasztják kutatásunk megállapításait, miszerint az anyavállalat HR-gyakorlatának átvitele a leányvállalatokhoz sokkal konzekvensebb a menedzseri munkaköröknél, mint az alacsonyabb szintủ beosztottak esetében.

2. táblázat

\section{HR-alrendszerek kialakítása és müködtetése}

\begin{tabular}{|c|l|c|c|}
\hline Sorrend & \multicolumn{1}{|c|}{ HR-területek } & \multicolumn{2}{|c|}{ Központi befolyás } \\
\hline 1. & Vezetöi kiválasztás & $97,70 \%$ & \multirow{2}{*}{ nagy } \\
2. & Vezetöi ösztönzés & $97,60 \%$ & \\
\cline { 1 - 3 }. & Vezetői tréning és személyzetfejlesztés & $97,60 \%$ & \\
\hline 4. & Vezetöi toborzás & $96,30 \%$ & \\
\hline 5. & Dolgozói ösztönzés & $64,40 \%$ & \multirow{2}{*}{ közepes } \\
\hline 6. & Létszámtervezés & $57,90 \%$ & \\
\hline 7. & Dolgozói tréning és személyzetfejlesztés & $56,10 \%$ & \multirow{2}{*}{ kicsi } \\
\hline 8. & Dolgozói toborzás & $38,60 \%$ & \\
\cline { 1 - 3 }. & Dolgozói kiválasztás & $36,80 \%$ & \\
\hline 10. & Munkaügyi kapcsolatok, szakszervezetek & $36,80 \%$ & \\
\hline
\end{tabular}

A nemzetközi vállalatok kihasználták a magyarországi átmenet kínálta lehetőségeket. Hiltrop (1991) a külföldi és a helyi tulajdonban lévő cégek gyakorlatát vizsgálta Belgiumban. Úgy találta, hogy a külföldi tulajdonban lévő vállalatok sokkal előbbre tartottak a modern HR-technikák használatában, és több erőforrást szentelnek a HR-nek, mint a hazai cégek. A multinacionális vállalatok különösen élen jártak az olyan modern HR-gyakorlatok alkalmazásában, amelyek a teljesítmény növelésére, a pénzügyi eredmények alkalmazottak felé történő kommunikálására, a munkakörbe való bevezetésre és a szervezeten belülről történő előléptetésre irányultak. A hazai cégek jobb eredményeket tudtak felmutatni a vitás kérdések rendezésében és az alkalmazotti panaszok kezelésében. Kutatásunk megerősíti, hogy a nemzetközi vállalatok a globális HR-megoldások segítségével megpróbálták visszaszorítani a gyenge magyar szakszervezeteket. Más forrásokból ismert (Héthy 1995; Makó et al. 2003 és Makó 2005), hogy Magyarországon a szakszervezetek szervezettségi szintje sokkal magasabb a helyi tulajdonban lévő vállalatoknál, mint a multinacionális cégek leányvállalatainál.

A privatizációt és az MNV-ek megjelenését követő három időszak (3-5. fázisok) alatt jelentősen visszaesett a felmérésben résztvevő cégeknél a munkaügyi kapcsolatok (szakszervezetek) szerepe. Ezt a tendenciát más korábbi hazai kutatások (Héthy 1995; 
Tóth 1998) és a legújabb Cranet ${ }^{14}$-vizsgálataink (Farkas et al. 2007) is megerösítették ${ }^{15}$. A nemzetközi cégek hazánkban is kihasználták azt a lehetőséget, amit a magyar átalakulás kínált számukra. A szakirodalomból jól ismert módon (amit a korábban már idézett Hiltrop (1991) már a 90-es évek elején nyugat-európai vizsgálataival igazolt) globális HRmegoldásokkal próbálták kifogni a szelet a helyi szakszervezeti mozgalom vitorláiból.

Valamelyest nőtt a kezdetekhez képest a tréning és a személyzetfejlesztés, valamint az ösztönzési-juttatási funkciók fontossága. Ezt pozitív tendenciáként is értékelhetjük, hiszen struktúraváltás és nagyobb racionalizálások után az elsőként említett terület a leányvállalati megújulás fontos eszközének tekinthetö (Pfeffer 1995). Az ösztönzés és juttatások fontosságát a leányvállalatok érettségének alakulása indokolja. Ma már nem az ilyen rendszerek struktúráinak kialakítása a fontos, hanem a legköltséghatékonyabb megoldások megtalálása a kulcskérdés.

\section{A HR-létszám alakulása}

Lawler (2006) kutatásában igen szoros korrelációt talált a HR-létszám aránya és az emberierőforrás-terület professzionalizmusa között. A nagy HR-létszámaránnyal rendelkező leányvállalatok sokkal hatékonyabban tudják - az említett szerző vizsgálata szerint - az anyavállalati rendszereket átvenni és adaptálni.

A 3. táblázatból kiolvasható, hogy a vállalati létszámok növekedésével közepes, pozitív korreláció figyelhető meg - 10\%-os szignifikancia szinten - mind a három időszak alatt a HR-létszám és a vállalati létszám között. A táblázatból az is kiderül, hogy az alacsony kontextusú kultúrákból érkezett cégeknél a gazdasági visszaesés és a jelenlegi időszakokban a HR-létszám növekedése negatív korrelációt mutat, inkább csökkent, szemben a más kultúrákból érkezett cégekkel.

A vizsgált szervezetek 72,9\%-ánál a HR-létszám meghaladja a 10 főt, 45,9\%-ánál pedig a 15 főt. Jelenleg a cégek 76,2\%-ánál 100 fönél kisebb létszám jut egy HR-szakemberre. Ez az adat jóval kedvezőbb képet mutat a szakirodalomban olvashatóknál (IBM - Towers Perrin 1991; Saratoga 2002 és Brewester et al. 2004) és azoknál az adatoknál, amelyeket más felméréseinknél meghatároztunk (Poór - Karoliny 2005; Poór 2005 és Farkas et al. 2007).

$\mathrm{Az}$ említett jelenség több tényezővel is magyarázható. Például azzal, hogy a mostani mintát kizárólag a külföldi tulajdonú cégek ún. „krémje” alkotta. Továbbá az is magyarázat lehet, hogy ezek a cégek jóval nagyobb számban láthatnak el regionális HR-feladatokat. Ebből kifolyólag az e területen tapasztalható folyamatos létszám-racionalizálás nem érte el a vizsgált cégek HR-apparátusainak többségét.

14 A Cranfield Networknek (CRANET) (az angliai Cranfield Business School által alapított és müködtetett Európai Emberi Erőforrás Kutatási Hálózat), a Pécsi Tudományegyetem Közgazdaságtudomány Kar Szervezés-Vezetés Tanszéke 2004 óta tagja.

15 A volt szocialista országokban (Szlovénia kivételével) drámaian csökkent - a korábbi 90\% feletti értékről 15-20\%-ra a magánszférában a szervezett dolgozók száma (Farkas et al. 2007). 


\section{Sikert hozó HR-kompetenciák}

Mindhárom időszakban fontos HR-menedzseri kompetencia volt az együttmüködés és üzleti partnerség, emellett a válaszadók kiemelték még a változás, a team-munka és a gyors döntéshozatal kompetenciáit. A kutatás eredménye összecseng Ulrich (1988) véleményével, hogy a sikeres HR-vezetőknek nem elég ismerniük a HR/IHRM módszereit (szerző kiemelése), hanem alapos áttekintéssel kell rendelkeznie az üzleti stratégiáról, jártasnak kell lenniük a változásmenedzsment és a szervezeti kultúra kérdéseiben. A jelzett szerző fontosnak tartja a hitelességet is.

3. táblázat

\section{A külföldi kiküldöttek és a HR-létszám a vállalat létszáma és a cég eredete függvényében}

\begin{tabular}{|c|c|c|c|c|c|c|c|c|c|}
\hline & & \multicolumn{3}{|c|}{ Külföldi kiküldöttek száma } & \multicolumn{3}{|c|}{ HR-szakemberek száma } & \multicolumn{2}{|c|}{ HR-szakemberek } \\
\hline & & SS & SL & $\mathrm{TL}$ & SS & SL & $\mathrm{TL}$ & Életkora & Neme \\
\hline \multirow{3}{*}{ 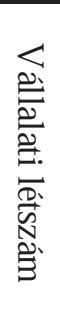 } & SS & $\begin{array}{r}, 443^{* *} \\
(, 003) \\
\end{array}$ & & & $\begin{array}{l}347^{* *} \\
(, 025) \\
\end{array}$ & & & & \\
\hline & SL & & & & & $\begin{array}{l}, 349^{* *} \\
(, 024) \\
\end{array}$ & & & \\
\hline & $\mathrm{TL}$ & & & $\begin{array}{l}, 670^{* *} \\
(, 000)\end{array}$ & & & $\begin{array}{l}, 338^{* *} \\
(, 028)\end{array}$ & & \\
\hline \multicolumn{2}{|c|}{$\begin{array}{l}\text { Cég eredet, alacsony } \\
\text { kontextusú kultúrából }\end{array}$} & & & & $\begin{array}{c}-, 318^{* *} \\
(, 040)\end{array}$ & $\begin{array}{c}-, 334^{* *} \\
(, 031)\end{array}$ & & $\begin{array}{c}-, 428^{* *} \\
(, 005)\end{array}$ & $\begin{array}{l}-, 306^{*} \\
(, 049)\end{array}$ \\
\hline & \multicolumn{9}{|c|}{ Magyarázatok: TL=átalakulás-tanulás, SL= globális-visszaesés, SS=napjaink } \\
\hline
\end{tabular}

A jövőben a HR-szakemberek sikere a nemzetközi vállalatoknál nagymértékben függ majd attól, hogy milyen interkulturális képességekkel bírnak (Briscoe - Schuler 2004). Meglepő módon az interkulturális képességeket a kutatás résztvevői nem értékelték kulcsfontosságú sikerfaktornak, valószínűleg azért, mert a válaszadók többsége csak helyi felelösségi körrel bírt.

A HR-kompetenciák hatékony megszerzési módja a formális HR-képzés, a kísérletező tanulás vagy a jelentős munkatapasztalat (Roehling et al. 2005). A felmérésben szereplö vállalatok a kompetenciák megszerzésének különböző módszereit közel egyenlő arányban alkalmazták. A legáltalánosabb módszerek a helyi és nemzetközi tréningek, valamint ezek bármely kombinációi voltak. Közel hasonló arányban használják a különféle kompetenciamegszerzési módokat a vizsgált cégek. Ezekből legjellemzőbbek a helyi, továbbá a nemzetközi tréning variációi és kombinációi. 


\section{A jövő}

A megkérdezettek az elkövetkező 12-24 hónap kulcskérdéseivel ${ }^{16}$ összefüggésben a következőketemeltékki: a résztvevővállalatok közel egyenlőarányban a hatékonyságnövelést, a globalizációhoz való alkalmazkodást, valamint a cégfejlesztés kérdéseit tekintették a legfontosabbnak. Nem tartották fontosnak az EU-integrációból adódó új HR-feladatokat. Ez utóbbihoz kapcsolódva fontos megjegyezni, hogy a nemzetközi cégek az elmúlt évek alatt nemzetközivé, „EU vonalassá” tették magyarországi HR-jüket.

\section{Következtetések és korlátok}

Hazai kutatási tapasztalataink azt mutatják, hogy Magyarországon a nemzetközi vállalatok HR-jében lezajlott a „rendszerváltás” (Danis - Parkhe 2002). A hazai gyakorlat számos területen mutat konvergenciát a korábban leírt HR jellegzetes nemzetközi tendenciáival, amelyek véleményünk szerint a H1-H7 hipotézisek tekintetében alábbiakban foglalhatók össze:

- H1: Az empirikus kutatásunk egyértelmüen igazolta, hogy a HR a privátszféra nemzetközi vállalatainál első számú stratégiai pozícióba került. A HR-részlegek sem a hazai nagyvállalatoknál, sem a külföldi tulajdonú leányvállalatoknál nem vesztették el funkciójukat. Nálunk sem igazolódott be az a jövendölés, miszerint a HR-részlegek elvesztették volna létjogosultságukat, és helyettük a vonalbeli vezetéshez került volna át a HR-munka felelőssége. Sőt, a nagyobb cégek HR-részlegei inkább magukhoz vonják, centralizálják a döntési-változtatási funkciókat. Csak közbevetőleg jegyezzük meg, hogy a világméretekben kibontakozó kiszervezési hullám (outsourcing) feltehetően e részlegek szerepét és funkcióját is jelentősen módosítani fogja a jövőben. A legtöbb HR-alrendszer (besorolás, teljesítményértékelés, bónusz stb.) kiépült a vizsgálatba bevont cégeknél. A bemutatott vizsgálatunk is jól alátámasztotta a saját és más hazai HR-mühelyek ${ }^{17}$ azon vélekedését, hogy az emberi erőforrások (a tudás, a képességek, a viselkedésmód) és menedzselésük a hosszú távú versenyképesség kulcsfontosságú feltételeivé váltak.

- H2: A magyar HR-szakemberek szerepe és gyakorlata összhangban van a helyi és a globális vállalati kultúra igényével. A HR-szakemberek felelőssége jóval túlmutat a munkavállalói érdekegyeztetéssel, valamint a fizetésekkel és juttatásokkal összefüggő feladatokon. A kommunikáció fontos HR-eszközzé vált.

- H3: Vizsgálataink visszaigazolták azt a hipotézisünket, miszerint a leányvállalatok különböző életciklusának fázisaiban eltérő HR-kérdések válnak fontossá. Az erő-

${ }^{16}$ A HRM jövőjével összefüggésben a szakirodalomban számos felfogással találkozhatunk: az első csoport az ún. állandóan bővülést elfogadók sorolhatók. Ezek a szakemberek a különböző befolyásoló tényezők (pl. technológia, kultúra, szabályozók stb.) változásával összefüggésben újabb és újabb területek irányába terjesztik ki a HR-tevékenységeket. Az óvatosak, a visszahúzódók csoportja úgy véli, hogy sok területen a menedzserek és az alkalmazók HRtudása miatt elveszíti létjogosultságát a HRM, és beépül a menedzserek mindennapi tevékenységébe. A jövőt kutató szakemberek harmadik csoportja úgy fogalmaz, hogy a befolyásoló tényezök olyan minőségi változáson mennek át, ami nyomán szükség van a HR szerepváltására. Ebbe beletartozik az is, hogy az új helyzetben nemcsak a HR szerepe, hanem a technológiája is megváltozik.

17 Itt gondolunk többek között a következő hazai szerzőkre: Kovács (1992), Kövári (1995), Gaál (1999), Poór et al. (1999), Bakacsi et al. (2002), Gyökér (1999), Pálinkás - Vámosi (2002), Roóz (2002), Karoliny et al. (2003), Makó et al. (2003), Újhelyi (2003), Fekete (2004), Tóthné (2004) és Bokor et al. (2005 és 2007). 
forrásbiztosítás a vizsgált 5 életciklus-fázisban mindig a leglényegesebb volt, amelyet a tréning és a személyzetfejlesztés követ.

- H4: A helyi leányvállalatok érettsége olyan fokot ért el, hogy a magyar menedzsereknek és szakembereknek számos lehetősége adódik arra, hogy bizonyítsanak a nemzetközi porondon. Az már más napra tartozik, hogy ezekkel a lehetőségekkel mennyire tudnak élni honfitársaink. Az empirikus adataink alapján leszögezhető, hogy struktúraváltást követő életciklus-időszakban csökken a külföldi kiküldöttek (expatriates) és nő a helyi, a központhoz kiküldött magyar szakemberek (impatriates) száma. Kutatásunk azt is visszaigazolta, hogy eltérést tapasztaltunk az előbbi megállapításunkat illetően a leányvállalatok (alacsony és magas kontextusú) kulturális háttere miatt.

- H5: A vizsgált nemzetközi cégeknél, föleg a vezetői munkakörök esetében, nagyobb a központ befolyása. Az alacsonyabb szintü munkakörök esetében a helyi HR szerepe jóval erősebb.

- H6: Kutatásunk is igazolta azt a hipotézisünket, miszerint a nemzetközi vállalatok leginkább a tréning- és a vezetésfejlesztési funkciókat szervezték ki külső szolgáltatóknak. A tanácsadás is széles körben elterjedt ezen a területen. Ennek két okát is megemlíthetjük a vizsgálatunkkal összefüggésben. Egyrészt ezt a területet hosszú évtizedeken keresztül nagyon háttérbe szorították ${ }^{18}$, és még napjainkban is pótlólagos szolgáltatásokra volt és van szükség. Másrészt pedig a globalizáció nagymérvű térnyerése nyomán a tanácsadókra még inkább igényt tartanak a nemzetközi cégek. Az outsourcing is gyerekcipőben jár hazánkban még, bár térnyerése (pl. szerződéses munkavállalók biztosítása, bérelszámolás, cafetéria) e területen is növekvő.

- H7: A szocializmus idején tapasztaltakkal szemben a magyar ipari dolgozók szervezettségi szintje egyáltalán nem volt magas a vizsgált cégek többségénél. A hazai ipar gerincét adó exportáló cégek többségénél a szakszervezetek szerepe visszaszorult vagy nem jelentős. $\mathrm{Ez}$ a trend összhangban van a korábban már említett szakirodalomi tapasztalatokkal (Hiltrop 1991, Héthy 1995 és Tóth 1998) és az elmúlt befejezett CRANET-kutatásainkkal (Farkas et al. 2007). A szervezett dolgozók jelenléte igazán csak bizonyos iparágakban (pl. olajipar, gyógyszeripar stb.) jelentős a nemzetközi cégek helyi leányvállalatainál.

A bemutatottempirikuskutatás a hazánkban működő nemzetközi vállalatokleányvállalataira terjedt ki. Az itteni tapasztalatok a rendszerváltás hasonló jellegéből, valamint a korábbi évtizedek szocialista HR-gyakorlata miatt kiterjeszthetők régiónk más országaira (pl. Csehország, Lengyelország). Azzal is tisztában vagyunk, hogy az intézményi, kulturális, jogi és történelmi különbségek miatt következtetéseink, javaslataink alkalmazása ezekben az országokban számos módosítással ültethetők csak át (Cui 2006).

18 Hazánkban a hagyományos emberierőforrás-menedzsment filozófiája ipari és termelési irányultságú volt a szocializmusban (Kövári 1995). A társadalmi célkitüzések középpontjában az ipari termékek és a tartós fogyasztási cikkek termelése állt, ehhez a munkaerő specializáltságának növelésére bürokratikus folyamatokat alkalmaztak. Ennek következményeként a szélesebb területeket lefedő emberierőforrás-menedzselés és a magasabb fokú személyi elkötelezettség újdonság volt a külföldi tulajdonú vállalatoknál dolgozók számára. 


\section{Hivatkozások}

Adizes, I. (1979): Organizational Passages -Diagnosing and Truly Lifecycle Problems of Organizations. Organizational Dynamics, 8:3-25.

Adizes, I. (1992): Vállalatok életciklusai. HVG Kiadó, Budapest.

Adler, N. (1997): International Dimensions of Organisational Behavior. PWS-Kent, Boston.

Baird, L. - Meshoulam, I. (1988): Managing two fits of strategic human resource management. Academy of Management Review, 13:116-128.

Bakacsi Gy. - Takács S. - Karácsony A. - Imrek V.. (2002): Eastern European cluster: tradition and transition. Journal of World Bussiness, 37:69-80.

Barakonyi K. (1999): Stratégiai tervezés. Nemzeti Tankönyvkiadó, Budapest.

Bartlett, C. A. - Ghoshal, S. (1998): Managing across Borders. The Transnational Solution. Harvard Business School Press, Cambridge.

Black, J. S. - Gregersen, H. - Mendenhall, M. - Stroh, L. (1999): Globalizing People Through International Assignments. Addison Wesley-Longmans, Reading, Mass.

Bokor A. - Bíró A. - Kováts G. - Takács S. - Toárniczky A. (2005): Vezetői elvárások és HR-es önképek. Munkaügyi Szemle, február:19-24.

Bokor A. - Szőts-Kovács K. - Csillag S. (2007): Emberi erőforrás menedzsment. Aula, Budapest.

Branyiczki I. - Bakacsi Gy. - Pearce, J. L. (1992): Back Door: Spontaneous Privatization in Hungary. Annals of Public \& Cooperative Economics. 2:303-324.

Brewster, C. (2004): European perspectives on human resource management. Human Resource Management Review, 4:365-382.

Brewester, Ch. (2007): Change and Continuity: The Cultural and Institutional Bases of Comparative and International HRM. 9th IHRM Conference, (Conference proceeding), Tallinn, June:12-14.

Briscoe, D. R. - Schuler, R. (2004): International Human Resource Management. Routledge, London.

Cui, A. S. - Griffith, A. D. - Causgil, S. T. - Dabic, M. (2006): The influence of market and cultural environmental factors on technology transfer between foreign MNCs and local subsidiaries: A Croatian illustration. Journal of World Business, 41:100-111.

Danis, W. - Parkhe, A. (2002). Hungarian-Western Partnerships: A Grounded Theoretical Model of Integration Processes and Outcomes. Journal of International Business Studies, 423-456.

Delany, E. (1998): Strategic development of multinational subsidiaries in Ireland. In: Birkinshaw, J. - Hood, N. (szerk.): Multinational corporate evolution and subsidiary development. St Martin's Press, NewYork.

Dowling, P. J. - Welch, D. E. (2004): International Human Resource Management. Thomson, London.

Dowling, P. J. - Festing, M. - Engle, A. D. (2008): International Human Resource Management. SouthWestern CENGAGE Learning, London.

Downs, A. (1967): The life cycle of bureaus. In: A. Downs (szerk.): Inside bureaucracy. Little, Brown \& Company and Rand Corporation, San Francisco.

Evans, P. - Pucik, V. - Barsoux, J. (2002): The Global Challenge: Frameworks for International Human Resource Management. McGraw-Hill/Irwin, Homewood.

Farkas F. (2004): Változásmenedzsment. KJK-Kerszöv, Budapest.

Farkas F. - Karoliny M.-né - Poór J. (2007): Human Resource Management in Hungary in Light of Eastern European and Global Comparison. (Conference proceeding) $9^{\text {th }}$ International Human Resource Management Conference, Tallinn, június:12-14.

Fekete I. (2004): Személyügyi szervezet. In: Tóthné S. G. (szerk.): Humánerőforrások gazdaságtana. Bíbor, Miskolc.

Fisher, C. D. - Schoenfeld, L. F. - Shaw, J. B. (1993): Human Resource management. Houghton-Mifflin, Boston.

Francesco, A. M. - Gold, B. A. (1997): International Organizational Behavior. Prentice Hall, Upper Saddle River.

Gaál Z. (1999): Emberi tőke - szervezeti kultúra. Harvard Business Manager, 1:69-74.

Gaál Z. - Szabó L. - Kovács Z. (2005): Nemzeti-vállalati kultúrák vizsgálata. OHE Személyügyi Hírlevél, 4.:24-35.

Greiner, L. (1972): Evolution and Revolution as Organizations Grows. Harvard Business Review, július augusztus:37-46. 
Greiner, L. E. - Metzger, R. O. (1983): Consulting to Management. Englewood Cliffs, New-York. Gyökér I. (1999): Humán erőforrás menedzsment. Műszaki, Magyar Minőség Társaság, Budapest. Hall, E. T. - Hall, M.R. (1989): Understanding cultural differences. Intercultural Press, Yarmouth.

Hanks, S. H. - Watson, C. J. - Jannsen, E. - Chandler, G. N. (1993): Tightening the life-cycle construct: A taxonomic study of growth stage configurations in high-technology organizations. Entrepreneurship: Theory and Practice, 2:5-30.

Harris, P. R. - Moran, R. T. (2001): European Leadership in Globalzation. In: Albrecht, M. H.: International HRM Managing Diversity in Workplace. Blackwell Business, Oxford.

Hellriegel, D - Slocum, J. W. - Woodman, R. W. (1998): Organizational Behavior. Thomson/ Southwestern, Cincinnati.

Hess, D. (1987): Relevance of small business courses to management needs. Journal of Small Business Management, 1:26-34.

Héthy L. (1995): Foglalkoztatás és foglalkoztatás politika Közép-Kelet-Európában. Munkaügyi Szemle, 7-8:10-17.

Hill, C. W. L. (2002): Global Business. McGraw-Hill, Boston.

Hiltrop, J. M. (1991): Human Resources Practices of Multinational Organizations in Belgium. European Management Journal, 4:404-411.

IBM - TP. (1991): Priorities for Competitive Advantage. A 21-st Century Vision: A Worldwide Human Resource Study. An IBM Study conducted by Towers Perrin. IBM - Towers - Perrin, New-York.

Karoliny M.-né - Farkas F. - László Gy. - Poór J. (szerk.) (2003): Emberi erőforrás menedzsment kézikönyv. KJK-Kerszöv, Budapest.

Katz, D. - Kahn, R. L. (1978): The social psychology of organizations. John Wiley Sons, New-York.

Kazanjian, R. K. - Drazin, R. (1989): A state-contingent model of design and growth for technology based new ventures. Journal of Business Venturing, 5: 137-151.

Kazanjian, R.K. (1988): Relation of dominant problems to stages of growth in technology based new ventures. Academy of Management Journal, 31:257-280.

Kieser, A. (1995): Szervezetelméletek. Aula, Budapest.

Kimberly, J. R. (1979). Issues in the creation of organizations: Initiation, innovation, and institutionalization. Academy of Management Journal, 22:437-457.

Kimberly, J. R. - Miles, R. H. (szerk.) (1980): The organizational life cycle: Issues in the creation, transformation, and decline of organizations. Jossey-Bass, San Francisco.

Kovács S. (1992): Vezetési struktúra és személyügyi funkció. Munkaügyi Szemle, 10:29-32.

Kővári Gy. (1995): Az emberi erőforrások fejlesztése. Szókratész, Budapest.

Kranhold, K. (2005): General Electric Names Vice Chairmen. The Wall Street Journal, június 24., A4.

KSH (2002): Magyar statisztikai évkönyv 2003. Központi Statisztikai Hivatal, Budapest.

László Gy. (2003): A munkaügyi kapcsolatok rendszere. In: Karoliny M.-né - Farkas F. - László Gy. - Poór J. (szerk.): Emberi eröforrás menedzsment kézikönyv. KJK-Kerszöv, Budapest.

Lauter, G. P. (1998): Világgazdasági kihívások az ezredfordulón. Európa Fórum, 1.

Lavery, B. - Ekman, I. (2005): „Europe's great migration”. The International Herald Tribune, október, 21, 4.

Lavoie, D. - Gulbert, S. A. (1978). Stages of organization and Development. Human Relations, 5:417-438.

Lawler, J. J. (2006): Cultural and Institutional Determinants of HR Systems in International Affiliates of American Multinational Corporations. Institute of Labor and Industrial Relations, University of Illinois.

Lippitt, G. - Schmidt, W. H. (1967): Crises in a developing organization. Harvard Business Review, 6:102112.

Makó Cs. - Warhurst, Ch. - Gennard, J. (szerk.) (2003): Emerging Human Resources Practices. Development and Debates in the New Europe. Akadémiai, Budapest.

Makó Cs. (2005): Neo-instead of post-Fordism: the transformation of labour processes in Hungary. International Journal of Human Resource Management, február:277-289.

Matus R. - Poór J. (2006): Külföldi kiküldöttek viszontagságai - japán expatok példái alapján. Munkaügyi Szemle, 2:20-24.

Miller, D. - Friesen, P. H. (1982): The Longitudinal Analysis of Organizations: A Methodological Perspective. Management Science, 9:1013-1033.

Oviatt, B. M. - McDougall, P. P. (1994): Towards a Theory of International Joint Ventures. Journal of International Business Studies, 1:45-64.

Pálinkás J. - Vámosi Z. (2002): Emberi Erőforrás Menedzsment. LSI Oktatóközpont, Budapest. 
Peng, M. W. (2009): Global Business. South-Western Cengage Learning, Mason (OH).

Pfeffer, J. (1994): Competitive advantage through people. Harvard Business School Press, Boston.

Poór J. - Farkas F. - Karoliny M.-né (1999) (szerk.): Személyzeti-Emberi erőforrás menedzsment. 3. kiadás, Közgazdasági és Jogi Könyvkiadó, Budapest.

Poór J. (2004): „Örökség” - A nemzetközi vállalatok leányvállalatai szerepének és fejlödésének HR vonatkozásai Magyarországon. Mercer Human Resource Management, Budapest.

Poór J. - Karoliny M.-né (2005): Konvergenciák és divergenciák az emberi eröforrás menedzsmentben. Vezetéstudomány, október:25-38.

Poór J. (2006): HR mozgásban - nemzetköziesedés az emberi erőforrás menedzsmentben. MMPC, Budapest.

Poór J. - Farkas F. - Karoliny M.-né (2007): Human Resource Management in Hungary in Light of Eastern European and Global Comparison. In: Estonian Business School Journal, 2:19-36.

Quinn, R. E. - Cameron, K. (1983): Organizational life cycles and shifting criteria of effectiveness: Some preliminary evidence. Management Science, 1:33-52.

Roehling, M. V. - Boswell, W. R. - Caligiuri, P. - Feldman, D. - Graham, M. E. - Guthrie, J. P. - Morishima, M. - Tansky, J. W. (2005): The future of HR management: Research needs and directions. Human Resource Management, 2:207-216.

Roóz J. (2002): Vállalkozások gazdaságtana. Perfekt, Budapest.

Rutherford, M. W. - Buller, P. F. - McMullen, P. R. (2003): Human Resource Management Problems over the Life-Cycle of Small to Medium-Sized Firms. Human Resource Management, 4:321-335.

Saratoga (2002): Benchmarking Report. Priorities for Competitive Advantage. A 21st Century Vision: A Worldwide Human Resource Study. Saratoga Institute, Santa Clara.

Schuler, R. S. - Dowling, P. J. - De Cieri, H. (1993): An Integrative Framework of Strategic International Human Resource Management. Journal of Management, 2:419-459.

Shenkar, O. - Nyaw, M. K. (1995): The Interplay of Human Resources in Chinese-Foreign Ventures. In: Shenkar O. (szerk.): Global Perspectives of Human Resource Management.Prentice Hall. Englewoods Cliffs.

Simai M. - Gál P. (2000): Ưj trendek és stratégiák a világgazdaságban. Akadémia, Budapest.

Taylor, S. - Beechler, S. - Napier, N. (1996): Toward an integrative model of strategic international human resource management. Academy of Management Review, 21:959-985.

Teng, A. (2006): The Cornerstone of HRO). HRO in Europe, március.

Torbert, W. R. (1974) Pre-bureaucratic and post-bureaucratic stages of organization development. Interpersonal Development, 5:1-25.

Toth, A. (1998): FDI and Industrial Relations in Central and Eastern Europe: The Exceptional Case of the Hungarian Airline. International Journal of Manpower, 2:115-124.

Tóthné S. G. (szerk.) (2004): Humán Eröforrások Gazdaságtana. Bíbor, Miskolc.

Ulrich, D. (1998): Human Resource Champions. Harvard Business School Press, Boston.

Újhelyi M. (2003): Ember és szervezet. Marketing \& Menedzsment, 4:37-49.

UNCTAD (2008): World Investment Report 2007. UN, Geneva.

White, R. - Poynter, T. (1984): Strategies for foreign-owned subsidiaries in Canada. Business Quarterly, nyár:59-69.

Wild, J. J. - Wild, K. L. - Han, J.Cy. (2003): International Business. Prentice Hall, New Jersey

Wiley, C (2002): HR Practices and Trends in Ireland 2001-2002 National Survey. Charted Institute of Personnel and Development Ireland, Dublin. 